\title{
Evidence for a tightly coupled nanoplanktonic predator-prey link regulating the bacterivores in the marine environment
}

\author{
Johan Wikner, Åke Hagström \\ Department of Microbiology, Umeå University, S-901 87 Umeå, Sweden
}

\begin{abstract}
A coupled predator-prey chain, starting with bacterivores, was investigated using the minicell recapture technique (MiniCap). Water samples were subjected to size fractionation with decreasing filter pore size, in order to obtain a successive truncation of the microbial food chain. Our results showed that the major bacterivores were flagellates in the size range of 1 to $3 \mu \mathrm{m}$. The truncation of the food chain caused increased or decreased predation on the bacteria, depending on whether the bacterivores were released from or subjected to increased predation pressure. We present a model describing trophic interactions between organisms less than $12 \mu \mathrm{m}$ in size. This model suggests 4 trophic levels to form a regulatory chain, exerting a tight control on major bacterivores.
\end{abstract}

\section{INTRODUCTION}

Growth of heterotrophic bacteria in the pelagic ecosystem appears to be balanced mainly by mortality due to predation (Fuhrman \& McManus 1984, Wright \& Coffin 1984, Wikner et al. 1986). Nanoflagellates and small ciliates have been proposed to be the major grazers on aquatic bacteria (Haas \& Webb 1979, Fenchel 1982a, b, Sherr et al. 1984, Andersen \& Fenchel 1985, Davies et al. 1985, Gast 1985). However, the sizes of potential bacterivores range from microplankton (20 to $200 \mathrm{um}$ ), such as dinoflagellates and nanociliates, to small organisms (picoflagellates) $<0.6 \mu \mathrm{m}$ (Fuhrman \& McManus 1984, Cynar et al. 1985, Gast 1985, Lessard \& Swift 1985).

Using prefiltration of natural samples and subsequent recording of changes in bacterial abundance, Wright \& Coffin (1984) suggested 1 to $3 \mu \mathrm{m}$ sized organisms to be the major grazers on bacteria. They assumed that a $1 \mu \mathrm{m}$. filtrate was predator free and calculated the bacterial growth from these samples. Using prokaryotic and eucaryotic inhibitors, Fuhrman \& McManus (1984) reported that $65 \%$ of the predation on bacteria might be caused by organisms less than $0.6 \mu \mathrm{m}$ in size. However, the use of 'predator free' controls and inhibitors when determining predation on bacteria have been questioned. Firstly, small bacterivores may pass a $1 \mu \mathrm{m}$ filter (Cynar et al. 1985). Secondly, removal of nutrient excreting protozoans may affect bacterial growth

(C) Inter-Research/Printed in F. R. Germany
(Sherr et al. 1986). Hence, bacterial growth in filtered samples may not reflect the actual bacterial production. Thirdly, prokaryotic and eucaryotic inhibitors might give incomplete inhibition of the target organisms and unwanted effects on the non-target organisms, which make the interpretation of the results obtained with this technique difficult (Sherr et al. 1986, Taylor \& Pace 1987). Thus, more direct measurements of the predation on pelagic bacteria are needed to determine predator-prey interactions in the microbial food web.

Investigations with this aim are scarce. However, one report by Rassoulzadegan \& Sheldon (1986) suggests several trophic interactions, even within the nanoplanktonic size range. Based on the development of different populations following size fractionation of water samples, these authors concluded that at least 4 predator-prey interactions occurred among organisms less than $10 \mu \mathrm{m}$ in size. Wright \& Coffin (1984) also noticed changes in eucaryotic numbers depending on pore size used during the prescreening and suggested this to be due to rupture of the normal trophic interactions. Hence, removal of organisms in trophic levels higher than the bacterivores might also affect the rate of predation on bacteria.

The minicell recapture technique (MiniCap, Wikner et al. 1986) has made it possible to monitor predation on natural sized heterotrophic bacteria in short-term experiments, without the need to know which kind of predators are present or to use antibiotics. In this paper 
we analyze the microbial community following size selective screening of water samples, in order to find the most important predators on pelagic bacteria and their regulation

\section{MATERIALS AND METHODS}

Main sampling sites were the routine station Systrarna in the Bothnian Sea (Hagström 1984) and Point B in the Bay of Villefranche-Sur-Mer in the Mediterranean Sea (Rassoulzadegan \& Sheldon 1986). Water was collected in 101 bottles from $4 \mathrm{~m}$ water depth; measurements were started within $2 \mathrm{~h}$ of sampling (about $10 \mathrm{am})$.

Size fractionations. Water samples of $1200 \mathrm{ml}$ were filtered in each size fractionation (Nuclepore Corp. Pleasanton, Calif., $47 \mathrm{~mm}$ diam.). Filters were changed for every $200 \mathrm{ml}$ of water. The 12 to $1 \mu \mathrm{m}$ filters requircd only gravity force, while 50 and $100 \mathrm{~mm} \mathrm{Hg}$ was applied during 0.6 and $0.2 \mu \mathrm{m}$ filtrations respectively. Filtrations always began with the smallest pore size to avoid contaminations by larger organisms during handling.

Water samples (10l) used for prolonged incubations were filtered as described above and incubated for $12 \mathrm{~h}$ (Mediterranean Sea) or $20 \mathrm{~h}$ (Bothnian Sea). As controls, the same volume of unfiltered water was incubated. Rate of predation on bacteria and bacterial production were measured simultaneously.

Rate of predation on bacteria. Filtrates $(1200 \mathrm{ml})$ and 1 unfiltered sample of water were transferred to $2.5 \mathrm{l}$ transparent polycarbonate bottles. Within $1 \mathrm{~h}$ of the start of the filtration procedure, genetically marked minicells, prepared from Escherichia coli M2141 containing the plasmid pACYC184, were added to water

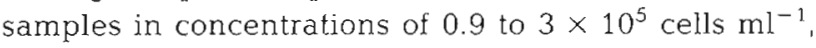
depending on the specific activity of the minicells (Wikner et al. 1986). The minicells were carefully mixed by gently inverting the bottle 25 times. The bottles were then incubated at ambient temperature and light conditions. Samples of $200 \mathrm{~m}$ l were collected on $0.2 \mu \mathrm{m}$ Nuclepore filters every hour during $4 \mathrm{~h}$ starting at time zero, and further treated as described by Wikner et al. (1986). Exceptions from this protocol were the use of Lumasolve (Lumac/3M, no, 1044) and Optjscint ' $T$ ' scintillation liquid (LKB, no. 1294) when extracting the marker proteins from the polyacrylamide gel, thus making the use of $\mathrm{H}_{2} \mathrm{O}_{2}$ and peroxidase unnecessary. Cpm-values were recalculated to give minicells $\mathrm{ml}^{-1}$ and the slope of the regression line provided the disappearance rate of minicells.

Bacterial production was measured in Bothnian Sea experiments 1986 and 1988, with the ${ }^{3} \mathrm{H}$-thymidine method according to Fuhrman \& Azam (1982). Incuba- tions were started $1 \mathrm{~h}$ after filtration. Samples (triplicates) were incubated $1 \mathrm{~h}$ with ${ }^{3} \mathrm{H}$-thymidine at a $10 \mathrm{nM}$ final concentration.

Yield experiment. In the Bothnian Sea experiment 1986, water samples were filtered as described above. Triplicate samples of $10 \mathrm{ml}$ from each filtrate were passed through a $0.2 \mu \mathrm{m}$ ( $25 \mathrm{~mm}$ diam.) Nuclepore filter and transferred to 3 test tubes. One ml of brackish water, filtered first through a $1 \mu \mathrm{m}$ and then through a $0.6 \mu \mathrm{m}$ filter (in order to remove the major bacterivores) was added to each test tube (final conc. of natural bacteria $2 \times 10^{5}$ cells $\mathrm{ml}^{-1}$ ). Tubes were incubated at room temperature for $48 \mathrm{~h}$, and preserved using a formalin-ethidium bromide solution (Hagström 1984). The final concentration of heterotrophic bacteria was then determined from direct counts.

Cell counts. Heterotrophic bacteria and flagellates were stained using either DAPI (Porter \& Feig 1980) or ethidium bromide (Hagström 1984) and counted in an epifluorescence microscope. One sample from each size fraction was filtered on a $0.2 \mu \mathrm{m}$ and $0.6 \mu \mathrm{m}$ Nuclepore filter, for the bacterial and flagellate counts respectively. Fifteen fields and 60 fields respectively, were counted to determine bacterial and flagellate abundance. Size of flagellates in the 1 and $3 \mu \mathrm{m}$ size fractions was determined by comparison with an ocular grid (G1, Graticules LTD, Tonbridge, Kent, England) during microscopy

\section{RESULTS}

\section{Predation rates}

Rates of predation on pelagic bacteria in size fractionated water samples with corresponding statistical data are tabulated in Table 1. Although the experiments cover different seasons (early summer to late autumn) and different locations (Bothnian Sea and Mediterranean Sea), a systematic effect of pore size used in the prescreening ( $p<0.001,2$-way ANOVA on all fractions and experiments) emerged (Fig. 1). A major decrease in predation rates was observed when pore sizes of $1 \mu \mathrm{m}$ and less were used in the prefiltration. This decline coincided with sharp decrease in flagellates (Table 3 ). The 5 and $3 \mu \mathrm{m}$ size fractions, which preceded this decline, showed the highest predation rates observed during the experiments (up to 1.7 times the rate in unfiltered water). Rates of predation in the $0.2 u \mathrm{~m}$ fraction were below the detection limit of the method.

Predation rates in the 10 um filtrates were also elevated compared to unfiltered samples, however less so than in the 5 to 3 um filtrates. In the 8 um filtrate the relative predation rate was dampened, as if the bac- 
Table 1. Predation rates $\left(\times 10^{4}\right.$ cells $\left.\mathrm{ml}^{-1} \mathrm{~h}^{-1}\right)$ in size fractionated water samples from 4 experiments. Standard error $( \pm \mathrm{SE})$, degrees of freedom $(\mathrm{df})$, coefficient of determination $\left(\mathrm{r}^{2}\right)$ and relative predation rate $(\%$ of unfiltered sample) are shown for each estimate. Systematic variation in relative predation rate was statistically significant $(p<0.02)$ according to 2 -way ANOVA (Statworks ${ }^{\mathrm{tm}}$ )

\begin{tabular}{|c|c|c|c|c|c|c|c|c|c|}
\hline & \multicolumn{9}{|c|}{ Size fraction $(\mu \mathrm{m})$} \\
\hline & Unfilt. & $<12$ & $<10$ & $<8$ & $<5$ & $<3$ & $<1$ & $<0.6$ & $<0.2$ \\
\hline \multicolumn{10}{|c|}{ Bothnian Sea 1985} \\
\hline Predation rate & 7.06 & 7.91 & 7.63 & 8.14 & 11.6 & 10.5 & 8.87 & 3.75 & 0.06 \\
\hline$\pm \mathrm{SE}$ & 0.739 & 3.90 & 3.21 & 1.17 & 1.07 & 3.90 & 2.92 & 0.414 & 0.050 \\
\hline $\mathrm{df}$ & 2 & 2 & 2 & 1 & 2 & 2 & 1 & 2 & 1 \\
\hline$r^{2}$ & 0.983 & 0.673 & 0.739 & 0.980 & 0.983 & 0.784 & 0.902 & 0.976 & 0.571 \\
\hline Rel. pred. (\%) & 100 & 112 & 108 & 115 & 165 & 149 & 126 & 53 & 9 \\
\hline \multicolumn{10}{|c|}{ Mediterranean 1986} \\
\hline Predation rate & 7.89 & 7.28 & 11.3 & 2.39 & 7.96 & 3.22 & 1.98 & 1.99 & 0 \\
\hline$\pm \mathrm{SE}$ & 1.40 & 1.98 & 2.02 & 1.31 & 0.362 & 1.30 & 0.548 & 0.479 & 0.007 \\
\hline df & 1 & 2 & 1 & 2 & 1 & 2 & 2 & 2 & 3 \\
\hline$r^{2}$ & 0.969 & 0.871 & 0.969 & 0.625 & 0.975 & 0.755 & 0.866 & 0.896 & 0.013 \\
\hline Rel. pred. $(\%)$ & 100 & 92 & 143 & 30 & 101 & 41 & 25 & 25 & 0 \\
\hline \multicolumn{10}{|c|}{ Bothnian Sea 1986} \\
\hline Predation rate & 22.9 & 22.3 & 30.4 & 19.2 & 31.2 & 38.3 & 8.54 & 1.73 & 0.01 \\
\hline $\pm S E$ & 2.28 & 2.66 & 1.60 & 6.566 & 4.84 & 6.10 & 5.09 & 6.13 & 0.098 \\
\hline df & 3 & 3 & 3 & 3 & 3 & 3 & 3 & 2 & 2 \\
\hline$r^{2}$ & 0.973 & 0.960 & 0.992 & 0.743 & 0.890 & 0.929 & 0.484 & 0.040 & 0.01 \\
\hline Rel. pred. (\%) & 100 & 97 & 133 & 84 & 136 & 167 & 37 & 7 & 0 \\
\hline \multicolumn{10}{|c|}{ Bothnian Sea 1988} \\
\hline Predation rate & 8.03 & 8.46 & 8.87 & 4.37 & 9.55 & 13.5 & 10.3 & 0 & 0 \\
\hline $\pm S E$ & 3.38 & 2.34 & 3.75 & 4.89 & 3.12 & 4.22 & 2.52 & 2.08 & 0.006 \\
\hline df & 4 & 3 & 4 & 4 & 2 & 4 & 4 & 4 & 4 \\
\hline$r^{2}$ & 0.381 & 0.876 & 0.586 & 0.128 & 0.824 & 0.626 & 0.805 & 0.040 & 0.012 \\
\hline Rel pred. (\%) & 100 & 105 & 111 & 54.4 & 119 & 168 & 128 & 0 & 0 \\
\hline
\end{tabular}

terivores had been repressed. Hence, a bimodal response in rate of predation, was found in the $>3 \mu \mathrm{m}$ size fractions (Fig.1). The systematic dependence of

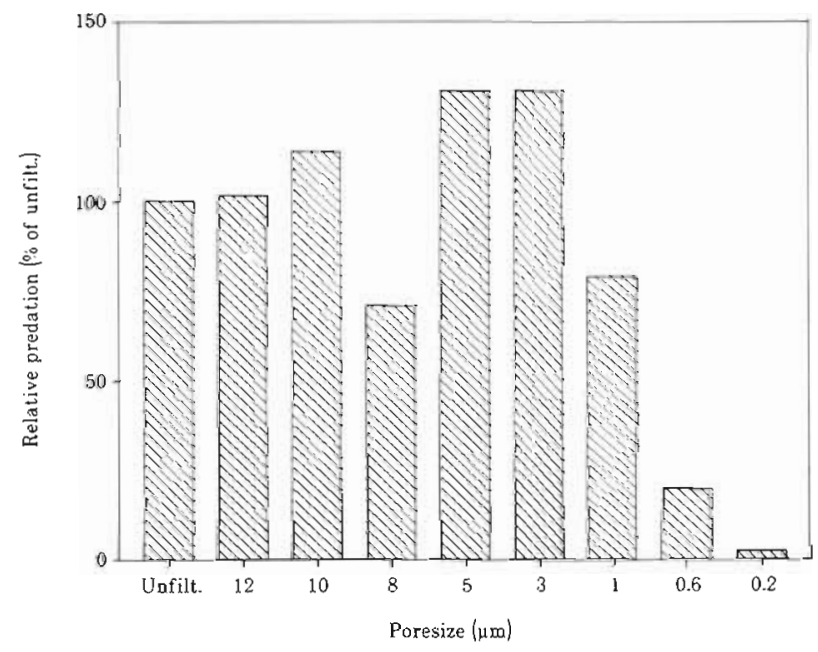

Fig. 1 Relative predation rates in size fractionated water samples compared to unfiltered water. Average rates in each of the size fractions from the 4 experiments (Table 1 ). Systematic dependence of pore size in the $>3 \mu \mathrm{m}$ size fractions was statistically significant $(p<0.02)$ according to 2 -way analysis of variance (Table 2 ) filter pore size found in the size fractions larger than $3 \mu \mathrm{m}$ was statistically significant $(p<0.02)$ according to a 2-way analysis of variance (Table 2 ).

\section{Abundance of flagellates}

Flagellate numbers were $6.7 \times 10^{2} \mathrm{ml}^{-1}$ in unfiltered water in the Mediterranean Sea experiment (Table 3) and showed a significant decrease after a $1 \mu \mathrm{m}$ filtra-

Table 2. Analysis of variance obtained by 2 -way ANOVA on all size fractions $>3 \mu \mathrm{m}$. Systematic dependence of the pore sizes used in prescreening (Fig. 1) was statistically significant $(p<0.02)$

\begin{tabular}{|lccccc|}
\hline Source & $\begin{array}{c}\text { Sum } \\
\text { of } \\
\text { squares }\end{array}$ & $\begin{array}{c}\text { Degrees } \\
\text { of } \\
\text { freedom }\end{array}$ & $\begin{array}{c}\text { Mean } \\
\text { squares }\end{array}$ & F-ratio & $\alpha$ \\
\hline $\begin{array}{l}\text { Between } \\
\text { experiments } \\
\text { Between } \\
\text { pore sizes }\end{array}$ & 2198 & 3 & 732 & 1.696 & 0.305 \\
$\begin{array}{l}\text { Error } \\
\text { Total }\end{array}$ & 8768 & 4 & 2192 & 5.073 & 0.013 \\
\hline
\end{tabular}


Table 3. Initial concentration of nanoflagellates in water samples prescreened with filters of different pore sizes. Values for prefiltered water presented as percentage of the concentration in unfiltered water Values in parentheses: $95 \%$ confidence interval for estimated mean value of unfiltered sample. NA: not available, ND: not determined

\begin{tabular}{|c|c|c|c|c|c|c|c|c|}
\hline \multirow[t]{2}{*}{ Location } & \multirow[t]{2}{*}{ Year } & \multirow{2}{*}{\multicolumn{2}{|c|}{$\begin{array}{l}\text { Unfiltered water } \\
\left\{\text { cells } \mathrm{ml}^{-1} \times 10^{3} \text { \} }\right.\end{array}$}} & \multicolumn{5}{|c|}{ Fraction $(\mu \mathrm{m})$} \\
\hline & & & & $<10$ & $<5$ & $\begin{array}{c}<3 \\
(\% \text { of unfilt. })\end{array}$ & $<1$ & $<0.6$ \\
\hline Mediterranean Sea & 1986 & 0.68 & (NA) & ND & 100 & 60 & 16 & ND \\
\hline Bothnian Sea & 1986 & 4.83 & $( \pm 0.63)$ & ND & 80 & 48 & 10 & $<0.7$ \\
\hline Bothnian Sea & 1988 & 10.1 & $( \pm 1.78)$ & 51 & 19 & 18 & 8 & $<0.7$ \\
\hline
\end{tabular}

tion, lowering the concentration to $24 \%$ of the unfiltered sample. In the 1986 Bothnian Sea experiment concentration of flagellates in unfiltered water was clearly higher, $4.8 \times 10^{3} \mathrm{ml}^{-1}$. Filtration with successively smaller pore sizes resulted in a gradual decrease in flagellate numbers which was most marked in the $1 \mathrm{um}$ filtrate. In early summer 1988 , the flagellate population was dense $\left(1.0 \times 10^{4} \mathrm{ml}^{-1}\right)$, with only $19 \%$ remaining in the $<3 \mu \mathrm{m}$ size fraction. The mean size of the organisms in the 1 and $3 \mu \mathrm{m}$ size fractions was $1.55 \mu \mathrm{m}( \pm \mathrm{SD} 0.17, n=30)$ and $2.28 \mu \mathrm{m}( \pm \mathrm{SD} 0.45$, $n=30$ ) respectively.

No organisms with flagellate characteristics were found in the $0.6 \mathrm{~m}$ filtrate, although other organisms, larger than heterotrophic bacteria, were present. In the unfiltered samples ciliates and copepods were observed but not counted. Hence, several possible predators on pelagic bacteria were present during the experiments.

\section{Bacterial production}

Bacterial production was unaffected by removal of the $>3 \mu \mathrm{m}$ organisms in the early summer experiment 1988 (Bothnian Sea) (Fig. 2B). Using 3 to $0.6 \mu \mathrm{m}$ filter pore sizes, the bacterial production was reduced to $75 \%$ of the rate in unfiltered water. Thus, the filter pore size used in the prescreening produced different effects on predation and growth of bacteria in this experiment.

In the autumn experiment 1986 (Bothnian Sea), rates of bacterial production showed a similar response to size fractionation as did the predation rate and was in absolute terms 2.5 times lower then the early summer experiment (Fig 2A). However, in the $3 \mu \mathrm{m}$ filtrate bacterial production decreased to a production rate corresponding to $60 \%$ of the activity in unfiltered water. No decrease in bacterial numbers or bacterivore activity was observed in this size fraction (Tables 1 and 4). Bacterial production decreased even further in the 1 and $0.6 \mathrm{um}$ filtrates, coinciding with the decline in bacterial numbers (Table 4). In accordance with the data on predation rates, we obtained increased bacterial

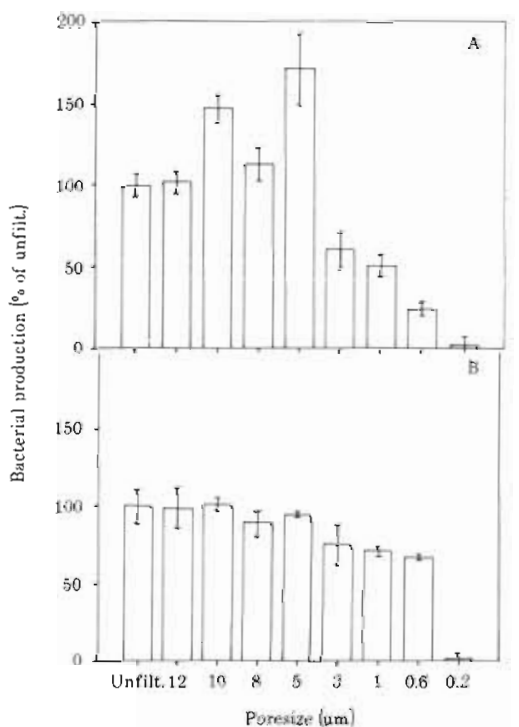

Fig. 2. Rate of bacterial production in water samples prescreened with different filter pore sizes. Bothnian Sea; (A) 1986, (B) 1988. Percentages of rates in unfiltered water $(1.5 \times$ $10^{4}$ and $3.9 \times 10^{4}$ cells $\mathrm{ml}^{-1} \mathrm{~h}^{-1}$, respectively). Differences found in the size fractions larger than 3 um (1986) were significant on a $0.1 \%$ level, according to 1-way analysis of variance

production in the 10 and $5 \mu \mathrm{m}$ filtrates, but not in the $8 \mu \mathrm{m}$ filtrate. The variations in the $>3 \mu \mathrm{m}$ size fractions showed a statistical significance of $p<0.1$ (1-way ANOVA). Thus, the effects of size fractionation on bacterial production and predation on bacteria with pore sizes larger than $3 \mu \mathrm{m}$ appeared to be synchronized in this experiment.

\section{Artificial release of utilizable DOM}

The amount of utilizable dissolved organic matter (DOM) released during filtration for each filter pore size, was determined with bacterial growth as a bioassay (Fig. 3, Bothnian Sea 1986). The yield of bacterial biomass was higher in the size fractions between 10 and 1 um than j.n the unfiltered water Peak values were found in the 10 to $8 \mu \mathrm{m}$ and the $3 \mu \mathrm{m}$ 
Table 4. Initial concentration of bacteria in water samples prescreened with filters of different pore sizes. Values for prefiltered water presented as percentages of the concentration in unfiltered water. Values in parentheses: $95 \%$ confidence interval for estimated mean value of unfiltered sample

\begin{tabular}{|c|c|c|c|c|c|c|c|c|c|c|c|}
\hline \multirow[t]{2}{*}{ Location } & \multirow[t]{2}{*}{ Year } & \multirow{2}{*}{\multicolumn{2}{|c|}{$\begin{array}{c}\text { Unfilt. water } \\
\text { (cells } \mathrm{ml}^{-1} \times 10^{6} \text { ) }\end{array}$}} & \multicolumn{8}{|c|}{ Fraction ( $\Perp \mathrm{m})$} \\
\hline & & & & $<12$ & $<10$ & $<8$ & $\begin{array}{l}<5 \\
1 \% 0\end{array}$ & $\begin{array}{r}<3 \\
\text { nfilt.) }\end{array}$ & $<1$ & $<0.6$ & $<0.2$ \\
\hline Bothnian Sea & 1985 & 1.27 & $( \pm 0.14)$ & 112 & 106 & 105 & 108 & 116 & 70 & 64 & 0 \\
\hline Mediter. Sea & 1986 & 093 & $( \pm 0.08)$ & 99 & 97 & 99 & 75 & 67 & 49 & 49 & 0 \\
\hline Bothnian Sea & 1986 & 2.78 & $( \pm 0.31)$ & 104 & 99 & 105 & 101 & 109 & 90 & 88 & 3 \\
\hline Bothnian Sea & 1988 & 1.56 & $( \pm 0.39)$ & 97 & 93 & 88 & 79 & 73 & 65 & 65 & 1 \\
\hline
\end{tabular}

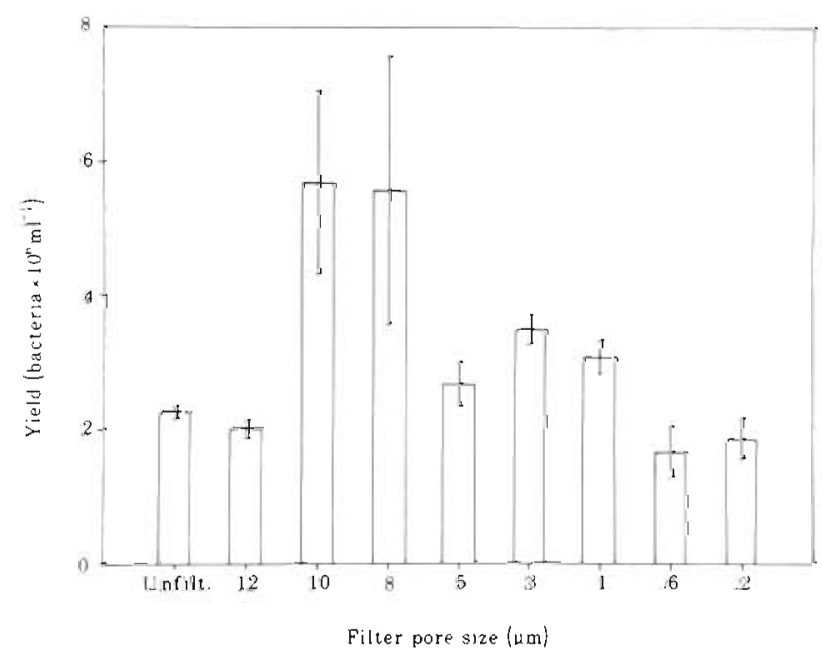

Fig. 3. Yield of bacterial biomass following a uniform inoculum of marine bacteria in water samples prescreened with different filter pore sizes. Bars: final concentration of

bacteria; lines: standard error of estimated mean value

filtrates. In the 0.6 and $0.2 \mu \mathrm{m}$ filtrates no increase in bacterial biomass were found, although a vacuum was applied during the filtrations $(50$ and $100 \mathrm{~mm} \mathrm{Hg}$ respectively). The standard error for each triplet of samples was higher in the 10 and $8 \mu \mathrm{m}$ filtrates indicating an uneven distribution of DOM sources in these filtrates. The size fractionation pattern obtained in the yield experiment showed a bimodal curve similar to that observed in the results of predation rate and bacterial production, however, peak heights and their location were shifted. Thus, release of DOM during the filtration procedure could not be clearly correlated with changes in bacterial production and predation rate in this experiment.

\section{Effect of prolonged incubation of prescreened samples}

In order to test if truncation of the microbial food chain could explain the effects observed on the bacterivore activity following prefiltration, the time between
Table 5. Rate of predation in water samples prescreened with different filter pore sizes 12 (Bothnian Sea) or $20 \mathrm{~h}$ (Mediterranean Sea) before measurement. Percentages of the rate in unfiltered water $\left(5.6 \times 10^{4}\right.$ cells $\mathrm{ml}^{-1} \mathrm{~h}^{1}$ and $3.1 \times 10^{4}$ cells $\mathrm{ml}^{-1} \mathrm{~h}^{-1}$ respectively). Standard error $(\%)$ and degrees of freedom shown in parenthesis. Variations were different from zero $(p<0.01)$ according to 2-way analysis of variance

\begin{tabular}{|c|c|c|c|}
\hline \multirow[t]{2}{*}{ Location } & \multicolumn{3}{|c|}{ Fraction ( $\mu \mathrm{m})$} \\
\hline & Unfilt. & $<10$ & $<3$ \\
\hline Bothnian Sea & $100(43,3)$ & $37(54,3)$ & $286(40,3)$ \\
\hline Mediterranean Sea & $100(25,1)$ & $36(3,3)$ & $243(58,2)$ \\
\hline
\end{tabular}

size fractionation and measurement was prolonged. Changes in predation rate on bacteria measured $20 \mathrm{~h}$ after size fractionation were in accordance with the results obtained $1 \mathrm{~h}$ after filtration (Table 5). That is, the bacterivore activity was repressed in the 10 um filtrate while being clearly increased in the 3 um filtrate. However, it was important to note that the observed responses were significantly greater after the prolonged incubation. This was probably caused by an increase in numbers of the top predator in the filtrate, as previously observed by Rassoulzadegan \& Sheldon (1986).

Effects of size fractionation on bacterial production were also maintained for at least $20 \mathrm{~h}$ (Table 6). The remaining production in the $3 \mathrm{um}$ filtrate $(60 \%$ of the

Table 6. Rate of bacterial production in water samples prescreened with different filter pore sizes 12 (Bothnian Sea) or $20 \mathrm{~h}$ (Mediterranean Sea) before measurement. Percentages of the rate in unfiltered water $\left(13.0 \times 10^{4}\right.$ cells $\mathrm{ml}^{-1} \mathrm{~h}^{-1}$ and 4.3 $\times 10^{4}$ cells $\mathrm{ml}^{-1} \mathrm{~h}^{-1}$ respectively). Standard error (\%) and number of replicates shown in parenthesis. Variations in each experiment were different from zero $(p<0.01)$ according to 1 -way variance analysis

\begin{tabular}{|lccccrc|}
\hline Location & \multicolumn{5}{c|}{$\begin{array}{c}\text { Fraction }(\mu \mathrm{m}) \\
<10\end{array}$} \\
& Unfilt. & $<3$ \\
\hline Bothnian Sea & $100(5.7,3)$ & 81 & $(3.2,3)$ & $58(4.7,3)$ \\
Mediterranean & $100(4.6,3)$ & 84 & $(2.9,3)$ & $172(1.7,3)$ \\
Sea & & & & & \\
\hline
\end{tabular}


rate in unfiltered water) was of the same relative size as when measured directly after size fractionation (Fig, 2A). The $3 \mu \mathrm{m}$ filtrate of Mediterranean water showed a less pronounced uncoupling of bacterial production and predation.

Thus, prolonged incubations confirmed results obtained directly after size fractionation, by showing similar but pronounced responses to the successive truncation of the microbial food chain.

\section{DISCUSSION}

\section{Food chain model}

To formalize the results obtained in this study we outlined a model describing the trophic interactions between organisms less than $12 \mu \mathrm{m}$ in size (Fig. 4). Removal of each level of predators was thought to give a rapid response in the activity of its prey due to the release of predation pressure. This change was propagated through a predator-prey chain in less than $2 \mathrm{~h}$ after truncation. Our data agreed with the existence of 3 predator levels above the bacterivore, and that the bacterial biomass was transferred in a serial manner through these trophic levels. Consumption of bacteria by the larger protozoa may have occurred, but seemed to be of minor importance.

Successive removal of organisms according to this model gave a response in the resulting bacterivore activity which was internally consistent with the observed results (Figs. 4 and 1). Thus, in our opinion a successive truncation of the microbial food chain was the most plausible explanation to the effects observed on the predation rate, as a result of the consecutive fractionation of water samples. Our experimental design did not allow monitoring of effects due to larger zooplankton or fish. However, the immediate short term control of the bacterivores did not seem to be influenced by other than nanoplankton. A successive transfer of the bacterial biomass through 4 trophic levels would mean that the contribution of bacterial carbon to the metazoan food chain was small. In one study supporting this scenario, Hagstrom et al. (1988) observed a daily transfer of $6 \%$ to higher trophic levels in an oligotrophic environment, where pelagic autoand heterotrophic production was dominated by the picoplankton size fraction. Instead, the microbial community mainly influenced the rate of transformation of organic matter to $\mathrm{CO}_{2}$ and inorganic nutrients.

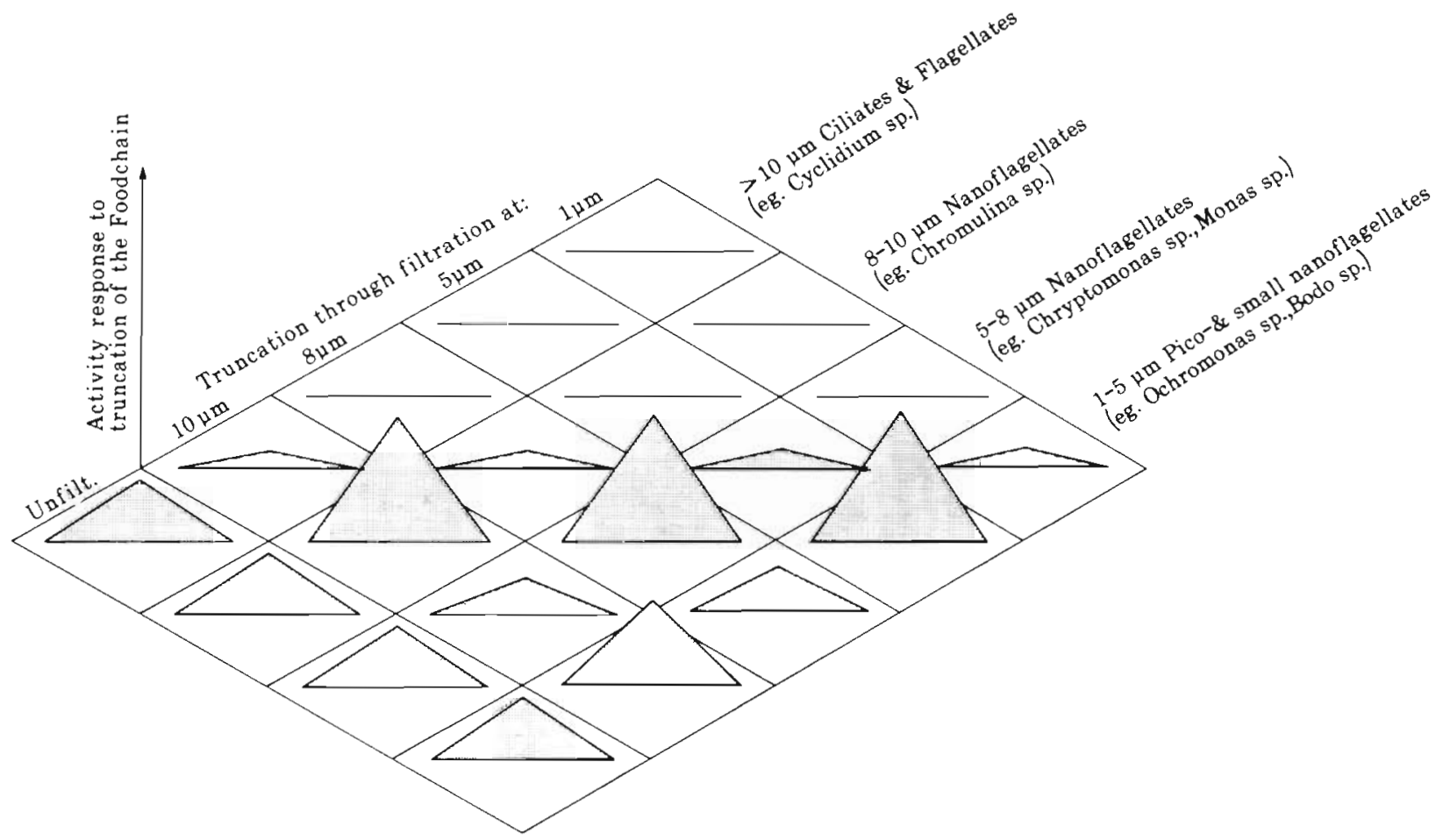

Fig. 4. Model of the microbial food chain. Height of symbols (z-axis): activity of organisms after truncation of food chain; triangles: protozoan predator-prey link; solid lines: organisms excluded by prefiltration. $y$-axis shows filter pore size used for truncation; maximum size range for each trophic level in these experiments is shown on x-axis. Species suggested for each trophic level have a suitable size and were known to be present in natural water samples during the time of experiments 


\section{Size of the bacterivore}

Rate of predation on bacteria was not lowered compared to unfiltered water until pore sizes of $1 \mu \mathrm{m}$ or less were used (Table 1, Fig. 1). Loss of predation could be expected if a bacterivore was totally retained by the filter or damaged during the passage. Since maximum predation rates observed were found in $3 \mu \mathrm{m}$ screened water, the major bacterivore must have passed quite unaffected through these pores. Accordingly, mean size of flagellates in the 1 and $3 \mu \mathrm{m}$ size fractions was 1.5 $( \pm \mathrm{SD} 0.17$ ) and 2.3 ( $\pm \mathrm{SD} 0.45) \mu \mathrm{m}$ respectively. Thus, we conclude that the most important predators on the free living pelagic bacteria were in the size range of 1 to $3 \mu \mathrm{m}$. In agreement with this conclusion, most of the minicell ${ }^{35} \mathrm{~S}$-label have been observed to be incorporated into this size fraction (Wikner et al. unpubl.).

Rassoulzadegan \& Sheldon (1986) argued that flagellates might pass pores half their cell width without damage. Therefore, the pore size used could slightly underestimate the size of the predator. However, even after $50 \mathrm{~h}$ of incubation of the filtered samples, populations developing in the filtrates had a size close to or smaller than the truncation point (Rassoulzadegan \& Sheldon 1986). Also, since the only protozoans we observed in the $<3 \mu \mathrm{m}$ size fraction were $2.8 \mu \mathrm{m}$ or smaller, we assume the larger organisms in this filtrate to be negligible in the time scale of our experiment.

The 1 to $3 \mu \mathrm{m}$ size fraction coincides with Population Il in the experiment of Rassoulzadegan \& Sheldon (1986), suggested by the authors to be picoflagellates exerting a predatory control over the bacterial size fraction. Furthermore, Wright \& Coffin (1984) reported that organisms 1 to $3 \mu \mathrm{m}$ in size were responsible for most of the observed decrease in bacteria in their experiment. Taken together, these data support the findings presented here. Recent papers have emphasized the importance of ciliates as grazers on free living bacteria (Gast 1985, Sherr \& Sherr 1987). However, our data unambiguously pointed towards nanoflagellates, in the size of 1 to $3 \mu \mathrm{m}$, as the most important predators on pelagic bacteria. Microprotozoa (20 to $200 \mu \mathrm{m}$ ) and larger nanoplankton are more likely to be important grazers on cyanobacteria and smaller nanoplankton as suggested by others (Iturriaga \& Mitchell 1986, Sheldon et al. 1986).

Predatory activity in filtrates that have passed a $0.6 \mu \mathrm{m}$ filter have been reported by Fuhrman \& McManus (1984), who found more than $60 \%$ of the grazing observed in unfiltered water in this size fraction. We also found bacterivore activity in this size fraction in 2 of our experiments (on average $16 \%$ of the predation activity found in the $5 \mu \mathrm{m}$ filtrate). Bacterivores of this size might be small flagellates that have passed undamaged (Fuhrman \& McManus 1984, Cynar et al. 1985, Rassoulzadegan \& Sheldon 1986), predatory procaryotes (Guerrero et al. 1986) and/or bacteriophages. Although it was definitely important to acknowledge that such organisms may be present, we chose to regard this activity as an inevitable spill-over in the size fractionation process.

\section{Predator-prey link}

The unexpected increase in predation rate in the 10 and 5 to 3 um filtrates indicated a derepression of predation on the bacterivores (Table 1, Fig. 1); that is, the bacterivores increased the grazing on bacteria due to a decrease in predation pressure on the bacterivores themselves. The increased grazing on bacteria could either be due to an increase in the per cell feeding rate of the bacterivores and/or number of bacterivores. In fact, assuming a generation time of $6 \mathrm{~h}$ for the bacterivores (Wikner et al. 1986), a $40 \%$ increase in abundance could be achieved within $3 \mathrm{~h}$ if removing its predator. The bimodal dependence of the predation rate with decreasing filter pore size found in all 4 experiments, suggested that there were at least 3 higher trophic levels that influenced the activity of the bacterivores in a consecutive way. In other words, removal of organisms $>10 \mu \mathrm{m}$ seemed to affect the bacterivores through a predator-prey chain, consisting of 3 trophic links. Fewer trophic links between truncation site and bacterivore (smaller pore size in the prefiltration) increased the strength of the measured effect on the bacterivore.

\section{Effects on bacterial production}

In the summer experiment (1988) a weak or no dependence between rate of predation on bacteria and amount of bacterial production in a given size fraction was observed (Fig. 2B). This showed that the pore size effect observed on the bacterivores was not caused by different rates of bacterial growth in the filtrates. However, the weak effects on bacterial growth in this experiment does not contradict the close dependence between predation and production found in the 1986 experiment (see below). In this experiment (autumn 1986, Bothnian Sea), bacterial production was clearly affected by the prefiltration, showing a similar response to size fractionation as did the predation rate (Fig. 2A). This result was also obtained in the prolonged experiments, where the effects were enhanced (Table 6).

Artificial increases in DOM, caused by the filtration, could theoretically have promoted bacterial growth 
which in turn stimulated the bacterivores. However, the result from the yield experiment did not explain the increase in bacterial production since a poor correlation between the parameters was found (Figs. 2B and 3). Instead, it may be argued that an increase in bacterial growth yield reflected the presence of organisms susceptible to shear forces in filters with appropriate pore size.

Hence, the close coupling found between predation on bacteria and bacterial production $\left(r^{2}=0.94, n=7\right)$ in the autumn experiment 1986, was most likely due to organisms ( 3 to $5 \mu \mathrm{m}$ ) included in the predator-prey link, which excreted nutrients crucial for the bacterial growth. It has been shown in laboratory experiments that nanoflagellates release nutrients which promote bacterial growth (Johannes 1965, Andersson et al. 1985, Caron et al. 1985). This may be more important for the growth of heterotrophic bacteria at oligotrophic conditions than previously thought (Hagström et al. 1988) and might be the reason for the co-regulation found between the predation on bacteria and the bacterial production (Wikner et al. 1986, this paper).

\section{Effects of prolonged incubation of prescreened samples}

Following the predator-prey link hypothesis outlined above, we would expect the largest organisms remaining in the filtrates after the prescreening procedure to be released from predation pressure. In agreement with this, we observed magnified effects on growth of and predation on bacteria when extending the incubation time following size fractionation (Tables 5 and 6). The predation rate in the 3 um filtrate was strongly elevated (2.5 times), compared to the unfiltered water, in both of the prolonged experiments, suggesting that a bacterivore close to, or smaller than, $3 \mu \mathrm{m}$ had been released from predation pressure (Table 5). Predation rate in the $10 \mu \mathrm{m}$ filtrate was lowered. The enhanced responses observed when measuring $12 \mathrm{~h}$ or more after size fractionation could be explained with greater changes in abundance of the remaining organisms in the filtrate (cf. Rassoulzadegan \& Sheldon 1986). These results support the previous statements that the changes found in rate of predation and bacterial production rate, when size fractionating sea water, was due to rupture of the normal trophic interactions and that the bacterivores were exposed to strong predation by larger protozoans.

Hence, the results presented in this paper unambiguously show that the main bacterivores were 1 to $3 . \mathrm{m}$ in size and controlled by predation rather than food supply Furthermore, the scenario presented in our model advocates the bacterivore population to be maintained in a balanced state in natural water, through close control between trophic levels. This tight regulation enables the organisms involved to adjust coordinately to changes in their environment. Finally, as a result of the existence of 4 trophic levels in the $<12 \mu \mathrm{m}$ size fraction, the bacterial biomass should be of minor importance as a food base for the metazoan food chain.

Acknowledgement. We thank Professor F. Rassoulzadegan for valuable support and advise. This work was supported by grants from the Swedish Natural Science Research Council no. B-BU-8583-102 and B-BU-4452-122.

\section{LITERATURE CITED}

Andersen, P., Fenchel, T (1985). Bacterivory by microheterotrophic flagellates in seawater samples. Limnol. Oceanogr 30 (1): 198-202

Andersson, A., Lee, C., Azam, F., Hagström, A. (1985). Release of aminoacids and inorganic nutrients by heterotrophic marine microflagellates. Mar. Ecol. Prog. Ser. 23: 99-106

Caron, D. A., Goldman, J. C., Andersen, O. K., Dennett, M. R. (1985). Nutrient cycling in a microflagellate food chain: II. Population dynamics and carbon cycling. Mar. Ecol. Prog. Ser 24: 243-254

Cynar, F. J., Estep, K. W., Sieburth, J. McN. (1985). The detection and characterization of bacteria-sized protists in 'protist-free' filtrates and their potential impact on experimental marine ecology. Microb. Ecol. 11. 281-288

Davies, P. G., Caron, D. A., Johnson, P. W. Sieburth, J. MCN. (1985). Phototrophic and apochlorotic components of picoplankton and nanoplankton in the North Atlantic: geographic, vertical, seasonal and diel distributions. Mar. Ecol. Prog. Ser 21. 15-26

Fenchel, T. (1982a). Ecology of Heterotrophic Microflagellates. II. Bioenergetics and growth. Mar. Ecol. Prog. Ser 8: $225-231$

Fenchel, T. (1982b). Ecology of Heterotrophic Microflagel.lates. IV. Quantitative occurrence and importance as bacterial consumers. Mar. Ecol. Prog. Ser 9: 35-42

Fuhrman, J. A., Azam, F. (1982). Thymidine incorporation as a measure of heterotrophic bacterioplankton production in marine waters: Evaluation and field results. Mar Biol. 66: $109-120$

Fuhrman, J. A., McManus, G. B. (1984). Do bacteria-sized marine eucaryotes consume significant bacterial production? Science 224: 1257-1260

Gast, V (1985). Bacteria as a food source for microzooplankton in the Schlei Fjord and Baltic Sea with special reference to ciliates. Mar. Ecol. Prog. Ser 22: 107-120

Guerrero, R., Pedrós-Alió, C., Esteve, I., Mas, J., Chase, D., Margulis, L. (1986). Predatory procaryotes: Predation and primary consumption evolved in bacteria. Proc natl icad. Sci. 83: 2138-2142

Haas, L. W., Webb, K. L. (1979). Nutritional mode of several non pigmented microflagellates from York river estuary, Virginia. J. exp. mar. Bıol. Ecol 39: 125-134

Hagstrom, $\AA$. (1984). Aquatic bacteria: measurements and significance of growth. In: Klug, M. J., Reddy, C. A. (eds.) Current perspectives in microbial ecology. American Society for Microbiology. Washington, D.C., p. 495-501

Hagström, A. Azam, F., Andersson, A., Wikner, J., Rassoulzadegan, F. (1988). Microbial loop in an oligotrophic pelagic marine ecosystem: possible roles of cyanobacteria 
and microflagellates in the organic fluxes. Mar. Ecol. Prog. Ser (in press)

Iturriaga, R., Mitchell, B. G (1986). Chrooccoid cyanobacteria: a significant component in the food web dynamics of the open ocean. Mar Ecol. Prog. Ser. 28: 291-297

Johannes, R. E. (1965). Influence of marine protozoa on nutrient regeneration. Limnol. Oceanogr. 10:434-442

Lessard, E. J., Swift, E. (1985). Species-specific grazing rates of heterotrophic dinoflagellates in oceanic waters, measured with dual lable technique. Mar. Biol 87: 289-296

Porter, K. G., Feig, Y. S. (1980). The use of DAPI for identifying and counting aquatic microflora. Limnol. Oceanogr 25: 943-948

Rassoulzadegan, F., Sheldon, R. W. (1986). Predator-prey interactions of nano-zooplankton and bacteria in an oligotrophic marine environment. Limnol. Oceanogr. 31 (5): 1010-1021

Sheldon, R. W., Nival, P., Rassoulzadegan, F. (1986). An experimental investigation of a flagellate-ciliate-copepod food chain with some observations relevant to the linear biomass hypothesis. Limnol. Oceanogr. 31 (1): 184-188
Sherr, B. F., Sherr, E. B., Newell, S. Y (1984). Abundance and productivity of heterotrophic nanoplankton in Georgia coastal waters. J. Plankton Res. 6: 195-202

Sherr, B. F., Sherr, E. B., Andrew, T L., Fallon, R. D., Newell, S. Y. (1986). Trophic interactions between heterotrophic protozoa and bacterioplankton in estuarine water analyzed with selective metabolic inhibitors. Mar. Ecol. Prog Ser. 32: 169-179

Sherr, E. B., Sherr, B. F. (1987). High rates of consumption of bacterla by pelagic ciliates. Nature, Lond. 325: 710-711

Taylor, G. T., Pace, M. L. (1987). Validity of eucaryotic inhibitors for assessing production and grazing mortality of marine bacterioplankton. Appl. environ. Microbiol. 53 (1): $119-128$

Wikner, J., Andersson, A., Normark, S., Hagström, A. (1986) Use of genetically marked minicells as a probe in measurement of predation on bacteria in aquatic environments Appl. environ. Microbiol. 52 (1): 4-8

Wright, R. T., Coffin, R. B. (1984). Measuring microzooplankton grazing on planktonic marine bacteria by its impact on bacterial production. Microb. Ecol. 10: 137-149

This article was submitted to the editor; it was accepted for printing on September 27, 1988 